\title{
Resistance of DB1 Transgenic Rice Line and others against Nilaparvata lugens, Brown Planthopper
}

\author{
Nono Carsono $^{1 *}$, Gigih Ibnu Prayoga ${ }^{2}$, Danar Dono ${ }^{1}$, Santika Sari ${ }^{1}$ and Kinya Toriyama ${ }^{3}$ \\ ${ }^{1}$ Lab of Plant Breeding, Faculty of Agriculture, Universitas Padjadjaran, Jatinangor Campus 45363, Indonesia \\ ${ }^{2}$ Dept of Agrotechnology, Faculty of Agriculture, Fisheries and Biology, Universitas Bangka Belitung 33172, Indonesia \\ ${ }^{3}$ Lab of Environmental Plant Biotechnology, Graduate School of Agricultural Science, Tohoku University, Sendai 980-8572, \\ Japan \\ *For correspondence: n.carsono@unpad.ac.id \\ Received 23 December 2020; Accepted 22 April 2021; Published 10 June 2021
}

\begin{abstract}
Nilaparvata lugens (Stål), brown planthopper (BPH) is as a major pest of rice crop. Developing rice resistant to BPH is an economically and environmentally friendly approach. A transgenic rice line with DBI (Dioscorea batatas tuber lectin 1) transgene has been engineered to overcome the problem. The objective of the experiment was to obtain the level of resistance of a DB1 rice line (DB1-inserted cv. Taichung 65) and some rice genotypes against two colonies of BPH. Resistance study was performed in BPH's preference, honeydew excretion, crop damage, and population development. The resistant test was carried out using two biotypes BPH i.e., biotype 2 (Sukamandi) and biotype 3 (North Sumatera). The result showed that DB1 transgenic rice was moderately resistant to biotype 2 , while to be susceptible when invested to biotype 3 , indicating that the $D B 1$ gene increases the resistance level, from susceptible to moderately resistant. All tested genotypes were chosen by biotype 2 for laying eggs, while for biotype 3 preferred five genotypes (DB1 transgenic line, PTB-33, Babawee, IR-64 dan IR-42). Genotype significantly differed on number of BPH and was considerably lower on PTB-33 than the others. Honeydew excretion of genotypes showed equal on biotype 2 and 3, except on biotype 3 of IR 42 (susceptible to BPH) which showing high amount of feces. PTB 33 had lower BPH population as compared to others, indicating high resistance to BPH of biotype 2 and 3 from Indonesia. (C) 2021 Friends Science Publishers
\end{abstract}

Keywords: Crop damage; DB1 transgenic rice; Honeydew test; Ovipositional test

\section{Introduction}

The brown planthopper (BPH), Nilaparvata lugens (Stål) (Homoptera: Delphacidae)) has been known as a major pest of rice cultivated in Asian countries. In most cases, large scale infestation of BPH may cause significant loss of rice production. Moreover, BPH also acts as vector for some viruses of diseases in rice such as stunt virus and ragged stunt virus (Nagadhara et al. 2004), which may cause more severe losses in rice yield. BPH infects plants by sucking the phloem sap and causes physiological stress or hopper burn. Development of resistance rice lines against BPH has been the ideal option for economic and effective management of BPH (Jena and Kim 2010). It is also safe for people and the environment and compatible with other current pest management strategies. Therefore, there is a need to prevent huge losses of rice yield by developing resistant rice lines through gene transfer technology as applied previously by Maqbool et al. (2001). The application of gene transfer technology has been recognized as an economical and environmentally sustainable approach which may reduce the application of insecticides.

By using agrobacterium-mediated gene transfer, $D B 1$ gene (Dioscorea batatas tuber lectin 1), which is isolated from yam tuber and is known as mannose-binding lectin family with $12-\mathrm{kDa}$ sub-units, has been inserted to develop rice plant resistance to sup-sucking insects (Toriyama 2010). Fifty eight percent of $D B 1$ nucleotide has homology with snowdrop lectin Gna, therefore classifying $D B 1$ into Gna-related lectin family (Gaidamashvili et al. 2004). Moreover, this gene has been shown to be effective against Helicoverpa armigera (Hübner) (Ohizumi et al. 2009) and Myzus persicae (Sulzer) (Kato et al. 2010) in Japan. Feeding $0.01 \%$ (w/v) DB1 corn to larvae of $H$. armigera was proven to reduce the larva population that survived until adulthood to $33 \%$ (Ohizumi et al. 2009). In another case, feeding 0.01 and $0.1 \%(\mathrm{w} / \mathrm{v})$ transgenic tobacco extract with $D B 1$ insertion decreased the surviving $M$. persicae (Sulzer) population to $60 \%$ (Kato et al. 2010). These results show the effectiveness of DB1 transgene that can be applied to 
develop transgenic rice plants resistant to sap-sucking insects. A transgenic rice cultivar (cv. Taichung 65) expressing DB1 transgene, driven by sucrose-synthase-1 $(R S s 1)$ promoter, has been successfully developed and a DB1 homozygous line directed by $R S s 1$ promoter has been selected. In the leaf of this plant, $D B 1$ accumulated at a level of $0.33 \%$ of total soluble protein (Toriyama 2010). Currently there is no report informing the resistance of $D B 1$ transgenic rice line to $\mathrm{BPH}$ especially to biotype 2 and 3 from Indonesia which is currently the most destructive pest of rice. The objective of this research was to determine the level of resistance of DB1 transgenic rice against those two biotypes of BPH. Testing for resistance was conducted for crop damage, BPH preference for laying eggs (oviposition), honey dew excretion and population build-up. Two colonies of BPH were used, i.e., biotype 2 (Sukamandi) and biotype 3 (North Sumatera) which are very abundance in certain rice-growing areas of the country.

\section{Materials and Methods}

\section{Plant materials and BPH colony preparation}

Transgenic Taichung-65 inserted with $D B 1$ transgene was tested for resistance to $\mathrm{BPH}$ together with eight other genotypes, i.e., Taichung-65, PTB-33, Rathu Heenati, IR64, IR-42, Babawee, Ciherang, and Cisadane, in a biosafety containment of Indonesia Centre for Agricultural Biotechnology and Genetic Resources Research and Development (ICABIOGRAD), Bogor. Two colonies of $\mathrm{BPH}$ were used as infection source. The first, biotype 2 (derived from Sukamandi) was obtained from The Indonesian Centre for Rice Research (ICRR) and the second one was biotype 3 (colony from North Sumatera) which was collected from Experimental Station of ICRR, Muara Bogor, Indonesia. Protocol for $\mathrm{BPH}$ rearing followed Matsumura et al. (2017) with modification. BPH adults used in the study were originally collected from a field population in Sukamandi and North Sumatera. For massrearing $\mathrm{BPH}$, the nylon screen cage by a small plastic jar was used. About 40-50 adult females of BPH were reared in inside the nylon screen covered by small plastic jar ( $15 \times 15$ x $20 \mathrm{~cm}$ ) containing rice plants cv. Ciherang for biotype 2, meanwhile rice $\mathrm{cv}$. IR-42 for biotype 3 and they were kept at room temperature $\left(26-28^{\circ} \mathrm{C}\right)$. After $48 \mathrm{~h}$, adult females were taken out from the jar using an aspirator and infested on $\mathrm{TN} 1$ rice line. The colonies were continually fed with $\geq$ 30-days old rice plants (TN1 host plant). Seven to ten days after infestation, the eggs were hatched and these BPH nymphal were used for further experiments.

\section{Testing for resistance of rice lines to $\mathrm{BPH}$}

Nine rice genotypes, including one transgenic line (DB1), three resistant (PTB 33, Rathu Heenathi, Babawee), three susceptible (IR 42, Ciherang and Cisadane) and IR 64 as a moderate resistant, were subjected to resistance assessment against BPH. The experiments were arranged in a completely randomized design with three replications. The design of experiment was also conducted for resistance to $\mathrm{BPH}, \mathrm{BPH}$ preference for laying eggs (oviposition), honey dew measurement and population build-up.

\section{Resistance test to BPH}

To evaluate resistance to $\mathrm{BPH}$ in rice genotypes, 20 seeds of each rice genotype were grown in a row of plastic box under greenhouse conditions (room temperature and natural lightly) (Matsumura et al. 2017). BPH infestation was carried out at the 2.5 leaf stage with second to third-instar $\mathrm{BPH}$ nymphs at a density of 3 nymphs per plant. After the dying the check plants (cv. Taichung 65 and IR 42), the seedlings were scored according to the Standard Evaluation System for Rice (IRRI 2013).

\section{Honeydew test (feeding activity test)}

Six-week-old rice seedlings were enclosed individually in parafilm plastic boxes with filter paper at the bottom. The filter paper was measured before and after treatment to identify the amount of honeydew excreted by BPH. Three couples of adult BPH were infested and after $24 \mathrm{~h}$, the BPH and filter papers were taken out of the box. The filter paper was sprayed with $0.01 \%$ solution of ninhydrin in acetone and then dried at $80^{\circ} \mathrm{C}$ for $24 \mathrm{~h}$. Honeydew excretion was observed by measuring the difference in weight of the paper filter before and after treatment.

\section{Ovipositional test}

To measure the number of eggs produced by $\mathrm{BPH}$, ten-dayold plants from each rice genotype were covered individually in parafilm plastic boxes followed KARC/NARO protocol (Matsumura et al. 2017). Three $\mathrm{BPH}$ gravid females were transferred to each cultivar and permitted to oviposit on the host plant. After seven days, oviposition was observed by counting the number of eggs on each cultivar (Matsumura et al. 2017).

\section{Population build-up of BPH}

Six-week-old of rice seedlings were enclosed individually in parafilm plastic box covered by mylar plastic sheets, $70 \mathrm{~cm}$ high and $12.5 \mathrm{~cm}$ in diameter and provided with three couples of adult BPH. Three days after infestation, the three couples of BPH were removed from the box and the observation started once $70 \%$ of nymphs had metamorphosed to adults. Population build-up data were obtained by counting the number of BPH in each cultivar after every two days until the susceptible cv. IR 42 and Taichung 65 died. Population build-up of the biotype 3 was recorded from $1^{\text {st }}$ (two days after $70 \%$ of nymphs 
metamorphosed into adult insects) to $7^{\text {th }}$ observation (14 days after $70 \%$ of nymphs metamorphosed into adult insects).

\section{Data analyses}

Resistance test to BPH was scored according to the Standard Evaluation System for Rice (IRRI 2013). BPH preference for laying eggs (oviposition), honeydew measurement and population build-up were analyzed using univariate by analysis of variance (ANOVA) and post hoc analysis by Duncan's Multiple Range Test (DMRT) and it was performed with the aid of SPSS v. 17.0 software.

\section{Results}

\section{Resistance test to BPH}

Based on the scale from the Standard Evaluation System for rice (IRRI 2013), the transgenic rice line (Taichung 65 DB1) had moderate resistance to biotype 2 (Tables 1,2), but was highly susceptible to biotype 3 (Table 3 ). These results indicated that $D B 1$ gene has no horizontal resistance as we expected it and is thus considered less effective against Indonesian $\mathrm{BPH}$ biotypes. However, DBI transgene improved resistance against $\mathrm{BPH}$ of the original genotype by one level, from susceptible (Taichung 65, original genotype) to moderately resistant (Taichung $65 \mathrm{DB} 1$ ) to biotype 2. PTB-33 and Rathu Heenati had better resistance to both BPH biotypes (Table 2 and 3). Meanwhile the highly susceptible was found in cultivars IR-42, Taichung 65-DB1 and Taichung 65 to biotype 3 (Table 3).

\section{Honeydew excretion test}

There were no significant differences in the amount of honeydew excreted by BPH biotype 2 and biotype 3 among genotypes tested (Table 4). However, the faeces amount of $\mathrm{BPH}$ biotype 3 was significantly higher on cv. IR-42 than on other genotypes (Table 4).

\section{Ovipositional response}

There was a significant difference in laying eggs both colonies as revealed in both Fig. 1-2. Almost all tested cultivars were chosen by $\mathrm{BPH}$ females of biotype 2 for laying their eggs, whereas Taichung-65 DB1, PTB-33, Babawee, IR-64 and IR-42 were much preferred by biotype 3. Transgenic DB1 line was significantly preferred by biotype 2 for laying eggs (Fig. 1). Taichung-65 DB1 showed significant differences on the number of eggs from cv. IR-64 for biotype 2, but no differences for biotype 3 . Fig. 1 and 2 also indicate no significant differences in egg number among high resistant genotype (PTB-33), resistant (Taichung-65 DB1, Rathu Heenati, Babawee, IR-64) and susceptible genotypes (IR-42 and Cisadane).

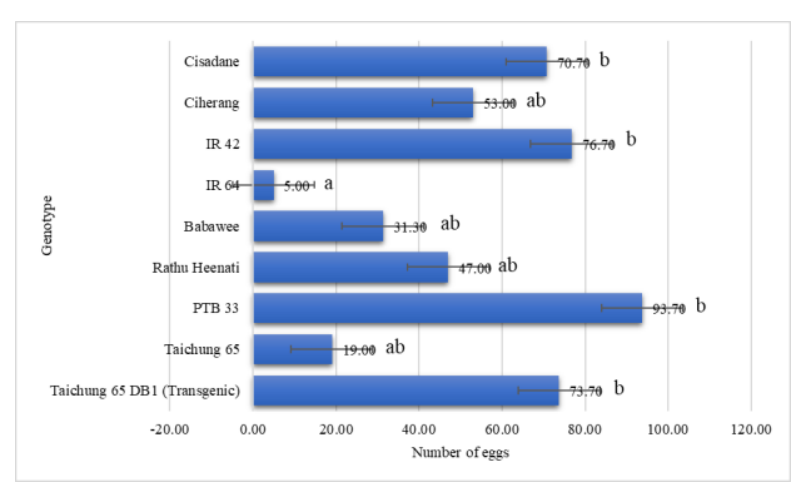

Fig. 1: Number of eggs of BPH biotype 2 at 7 days after infestation on some rice genotypes. The same letters were not significantly different according to Duncan's Multiple Range Test at 0.05 probability

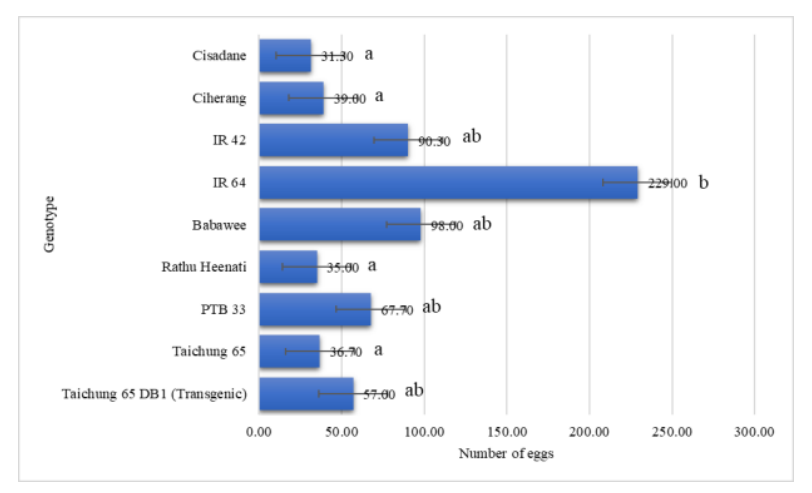

Fig. 2: Number of eggs of BPH biotype 3 at 7 days after infestation on some rice genotypes. The same letters were not significantly different according to Duncan's Multiple Range Test at 0.05 probability

\section{Population build-up of biotype 3 (Colony North Sumatera) of BPH}

Population development of the biotype 3 was recorded from $1^{\text {st }}$ (two days after $70 \%$ of nymphs metamorphosed into adult insects) to $7^{\text {th }}$ observation (14 days after $70 \%$ of nymphs metamorphosed into adult insects). There were no significant differences in total number of BPH population among nine genotypes at $1^{\text {st }}$ observation (two days after $70 \%$ of nymphs metamorphosed into adult), whereas significant different in total number of BPH were obtained at $2^{\text {nd }}$ observation (four days after $70 \%$ of nymphs metamorphosed) to $7^{\text {th }}$ observation (the last observation) (Table 5). The population of BPH on PTB-33 was the lowest. Compared to other cultivars, the population build up of BPH on PTB-33 was significantly lower at $1^{\text {st }}$ to $7^{\text {th }}$ observation.

\section{Discussion}

The present study indicated the resistance of transgenic DB1 and other genotypes to BPH biotype 2 and 3 from Indonesia 
Table 1: Scoring BPH resistance levels

\begin{tabular}{|c|c|c|}
\hline Score & Symptoms & Resistance Level \\
\hline 0 & No injury & Highly resistant \\
\hline 1 & Slight yellowing of a few plants & Resistant \\
\hline 3 & Leaves partially yellow but with no hopper burn & Moderately resistant \\
\hline 5 & Leaves with pronounced yellowing and stunting or wilting and $10-25 \%$ of plants with hopper burn, remaining plants severely stunted & Moderately susceptible \\
\hline 7 & More than half the plants wilting or with hopper burn, remaining plants severely stunted & Susceptible \\
\hline 9 & All plants dead & Highly susceptible \\
\hline
\end{tabular}

Table 2: Resistance level of rice genotypes after infested by Biotype 2 (colony Sukamandi)

\begin{tabular}{llll}
\hline No. & Genotype & Damage level & Resistance level \\
\hline 1 & PTB-33 & 0.70 & Highly Resistant \\
2 & Rathu Heenati & 1.58 & Resistant \\
3 & Babawee & 1.68 & Resistant \\
4 & IR-64 & 4.00 & Moderately Resistant \\
5 & Cisadane & 4.20 & Moderately Resistant \\
6 & Taichung 65 DB1 (Transgenic) & 4.82 & Moderately Resistant \\
7 & Ciherang & 5.27 & Moderately Susceptible \\
8 & IR-42 & 5.43 & Moderately Susceptible \\
9 & Taichung 65 (non-transgenic) & Susceptible \\
\hline Note: - Damage level on scale of 1-9 (IRRI 2013) were observed after susceptible cultivars died
\end{tabular}

- Nine rice cultivars were planted in lined plastic tray, with 20 plants per line, repeated 3 times, and infested by 3 of $3^{\text {rd }}$ instar of BPH

Table 3: Resistance level of rice cultivars after infested by Biotype 3 (colony north Sumatera)

\begin{tabular}{llll}
\hline No. & Cultivars & Damage level & Resistance level \\
\hline 1 & PTB-33 & 0.00 & Highly Resistant \\
2 & Ratu Heenati & 0.37 & Highly Resistant \\
3 & IR-64 & 3.10 & Moderately Resistant \\
4 & Ciherang & 3.80 & Moderately Resistant \\
5 & Cisadane & 4.10 & Moderately Resistant \\
6 & Babawee & 5.98 & Moderately Susceptible \\
7 & IR-42 & 9.00 & Highly Susceptible \\
8 & Taichung 65 DB1 (Transgenic) & 9.00 & Highly Susceptible \\
9 & Taichung 65 (non- Transgenic) & 9.00 & Highly Susceptible \\
\hline
\end{tabular}

Note: - Damage level on scale of 1-9 (IRRI 2013) were observed after susceptible cultivars died

- Nine rice cultivars were planted in lined plastic tray, with 20 plants per line, repeated 3 times, and infested by 3 of $3^{\text {rd }}$ instar of BPH

i.e., Sukamandi, West Java for biotype 2 and North Sumatra for biotype 3. Resistance reaction of transgenic rice line (Taichung 65 DB1) was moderate to biotype 2, but highly susceptible to biotype 3 . These results indicated that $D B 1$ gene has no horizontal resistance as we expected previously and is thus considered less effective against Indonesian BPH biotypes. However, DBI transgene improved resistance level against BPH of the original genotype by one level, from susceptible (Taichung 65, original genotype) to moderately resistant (Taichung 65 DB1) to biotype 2 . PTB33 and Rathu Heenati had better resistance to both BPH biotypes (Table 2 and 3 ).

Overall results indicate the possibility of obtaining genotypes with high resistance to BPH by using PTB-33 and Rathu Heenati as donor parents through common breeding program besides using a transfer gene method (as in the DB1 case) although it may take several years to be accomplished. PTB-33 and Rathu Heenati have been known to be highly resistant to various biotypes of $\mathrm{BPH}$, possibly because both cultivars possessed some BPH resistance genes such as Bph3, which is located on chromosome 6 (Jairin et al. 2007a), Bph2 and Bph3 (Santhanalakshmi et al. 2010) and other resistance genes against BPH. Moreover (Jairin et al. 2007b), clarified that Bph3 of Rathu Heenati and Bph3 of PTB-33 are linked with Bph4 of Babawee.
Information concerning the existence of DNA markers (SSR markers) which linked with resistance genes in both cultivars (Jairin et al. 2007b; Santhanalakshmi et al. 2010) would be beneficial for performing marker-assisted backcrossing programs or gene pyramiding (combining several resistant genes into one genotype) to develop cultivars with durable resistance against BPH.

The feeding response of $\mathrm{BPH}$ is assessed through amount of honeydew, its related to resistance or susceptibility of the genotype. This indicates that an interaction between $\mathrm{BPH}$ and rice plant exists to establish its host plant. Ling and Weilin (2016) have demonstrated that biochemical mechanisms rice resistance to BPH. According to Manuwoto and Adijuwana (1991) BPH feeding activities are performed through several stages i.e., (i) recognizing and orientating toward the host plant, (ii) tasting the food, (iii) assuring the food and (iv) sceasing to eat. Each stage is implemented by insects when the plant releases a specific signal or stimulus that they receive, and hence the plant does not provide a barrier that could inhibit BPH feeding activities. These conditions might establish a plant-pest interaction. However, Cheng et al. (2013) stated that feeding behaviors of $\mathrm{BPH}$ are complicated in that they are mainly related to host resistance, indicating a gene for gene relationship. Further molecular studies revealed that plant 
Resistance of DB1 Transgenic Rice Line and others to Brown Planthopper / Intl J Agric Biol, Vol 26, No 1, 2021

Table 4: Test for measuring amount of honeydew excreted by BPH biotype 2 and biotype 3 in nine rice genotypes

\begin{tabular}{|c|c|c|c|c|c|}
\hline \multirow{3}{*}{$\begin{array}{l}\text { No. } \\
1\end{array}$} & \multirow{3}{*}{$\begin{array}{l}\text { Genotype } \\
\text { Taichung-65 DB1 (Transgenic) }\end{array}$} & \multicolumn{4}{|c|}{ Feces amount (g) } \\
\hline & & \multicolumn{2}{|c|}{ Biotype 2} & \multicolumn{2}{|c|}{ Biotype 3} \\
\hline & & 0.0217 & $\mathrm{a}$ & 0.5710 & $\mathrm{a}$ \\
\hline 2 & Taichung 65 & 0.0311 & $\mathrm{a}$ & 0.5786 & $\mathrm{a}$ \\
\hline 3 & PTB 33 & 0.0386 & $\mathrm{a}$ & 0.5484 & $\mathrm{a}$ \\
\hline 4 & Rathu Heenati & 0.0001 & $\mathrm{a}$ & 0.5608 & $\mathrm{a}$ \\
\hline 5 & Babawee & 0.0008 & $\mathrm{a}$ & 0.5674 & $\mathrm{a}$ \\
\hline 6 & IR 64 & 0.0000 & $\mathrm{a}$ & 0.5819 & $\mathrm{a}$ \\
\hline 7 & IR 42 & 0.0000 & $\mathrm{a}$ & 0.6888 & b \\
\hline 8 & Ciherang & 0.0207 & $\mathrm{a}$ & 0.5911 & $\mathrm{a}$ \\
\hline 9 & Cisadane & 0.0064 & $\mathrm{a}$ & 0.5515 & $\mathrm{a}$ \\
\hline
\end{tabular}

Table 5: Number of BPH of biotype 3 on some rice genotypes

\begin{tabular}{|c|c|c|c|c|c|c|c|c|c|c|c|c|c|c|c|}
\hline \multirow[t]{2}{*}{ No } & \multirow[t]{2}{*}{ Genotypes } & \multicolumn{14}{|c|}{ Observation day } \\
\hline & & 1 & & 2 & & 3 & & 4 & & 5 & & 6 & & 7 & \\
\hline 1 & Taichung-65 DB1 (Transgenic) & 1.0 & $\bar{a}$ & 0.3 & $\mathrm{a}$ & 11.0 & $\mathrm{ab}$ & 17.3 & bcd & 44.3 & $\mathrm{~b}$ & 50.0 & $\mathrm{~b}$ & 57.3 & $\mathrm{~b}$ \\
\hline 2 & Taichung 65 & 0.0 & $\mathrm{a}$ & 1.7 & $\mathrm{ab}$ & 7.0 & $a b$ & 11.0 & $\mathrm{abc}$ & 44.7 & $\mathrm{~b}$ & 58.7 & $\mathrm{~b}$ & 71.7 & b \\
\hline 3 & PTB 33 & 1.0 & a & 0.0 & $\mathrm{a}$ & 1.0 & a & 2.3 & $\mathrm{a}$ & 2.7 & $\mathrm{a}$ & 3.3 & $\mathrm{a}$ & 1.0 & $\mathrm{a}$ \\
\hline 4 & Rathu Heenati & 2.0 & a & 9.0 & $a b$ & 23.3 & b & 25.7 & $\mathrm{~cd}$ & 58.7 & $\mathrm{~b}$ & 66.0 & $\mathrm{~b}$ & 97.0 & $\mathrm{~b}$ \\
\hline 5 & Babawee & 7.0 & $\mathrm{a}$ & 56.7 & $\mathrm{c}$ & 83.3 & $\mathrm{c}$ & 86.0 & d & 117.7 & $\mathrm{~b}$ & 131.0 & $\mathrm{~b}$ & 142.7 & $\mathrm{~b}$ \\
\hline 6 & IR 64 & 0.7 & $\mathrm{a}$ & 2.7 & $a b$ & 4.3 & $a b$ & 5.7 & $a b$ & 38.3 & $\mathrm{a}$ & 41.7 & $\mathrm{a}$ & 57.0 & $\mathrm{~b}$ \\
\hline 7 & IR 42 & 5.3 & $\mathrm{a}$ & 4.0 & $a b$ & 21.7 & $a b$ & 28.0 & bcd & 54.0 & $\mathrm{~b}$ & 62.0 & $\mathrm{~b}$ & 117.3 & $\mathrm{~b}$ \\
\hline 8 & Ciherang & 1.3 & $\mathrm{a}$ & 0.0 & $\mathrm{a}$ & 21.0 & $\mathrm{~b}$ & 26.7 & $\mathrm{~cd}$ & 105.3 & $\mathrm{~b}$ & 131.3 & $\mathrm{~b}$ & 139.7 & $\mathrm{~b}$ \\
\hline 9 & Cisadane & 0.7 & $\mathrm{a}$ & 18.3 & $\mathrm{~b}$ & 31.0 & $\mathrm{~b}$ & 35.0 & $\mathrm{~cd}$ & 47.7 & $\mathrm{~b}$ & 61.7 & $\mathrm{~b}$ & 60.3 & $\mathrm{~b}$ \\
\hline
\end{tabular}

Note: Numbers followed by the same letter in the same column were not significantly different according to Duncan's Multiple Range Test at 0.05 probability level. The observations were conducted from two days after $70 \%$ of nymphs metamorphosed into imago ( $1^{\text {st }}$ observation) to 14 days later $\left(7^{\text {th }}\right.$ observation $)$

hormones such as salicylic acid and jasmonate/ethylene (Wang et al. 2020), $\mathrm{Ca}^{+2}$ ion, mitogen-activated protein kinases (MAPKs) (Nanda et al. 2018) and OsRac1 play important roles in the immune response of rice to $\mathrm{BPH}$ (Cheng et al. 2013).

$\mathrm{BPH}$ ovipositional response as indicated by the number of eggs. No significant differences among the highly resistant genotype (PTB-33), resistant (Taichung-65 DB1, Rathu Heenati, Babawee, IR-64) and susceptible genotypes (IR-42 and Cisadane; Fig. 1 and 2) on the number of eggs for biotype 2 . These results indicate that the other factor may cause BPH interested in laying eggs, although in highly resistance cultivars, BPH did not suck the plant sap excessively (Pathak and Khan 1994; Rashid et al. 2016). It was considered that laying eggs and feeding (sucking the plant sap) as different activity and no linear relationship between these two activities. However, Horgan et al. (2018) found that PTB 33 become unsuitable for egg laying after the plant reaches maturity, indicating inability of $\mathrm{BPH}$ to insert eggs into maturing tissues of the plant. Furthermore, there are several stages of BPH in laying eggs on the plant, i.e., (i) recognition and orientation to the host plant, (ii) orientation in certain parts of the host plant, (iii) and then laying eggs (Cheng et al. 2013). Each stage is implemented by insects if plants released a specific signal or stimulus that was received by insects, and plant do not provide a barrier that could inhibit insects in laying the eggs (Kumari and Kaushik 2016).

Addressing no decrease of BPH populations on DB1 transgenic rice line from the $3^{\text {rd }}$ to the last observation, the number tended to increase (Table 5). These results reveal that the $D B 1$ transgene is considered less effective against
BPH biotype 3 than resistant genes on PTB 33. These results also indicate that there are $\mathrm{BPH}$ preferences to increase number of BPH population on preferred cultivars. In addition, there were mechanisms that possible to inhibit growing population of BPH as shown on PTB 33.

A significant low number of BPH populations at $1^{\text {st }}$ to $7^{\text {th }}$ observation on PTB 33 could be attributed by genetic composition of the plant. The resistance trait of PTB 33 is controlled by one major gene with some minor genes or determined by quantitative inheritance (Nugaliyadde et al. 2007). In addition, Sarao and Bentur (2018) found that PTB 33 has lower nymphal survival compared to other genotypes i.e., Rathu Heenati and Sinnasivappu. The authors also reported that nymphal emergence, nymphal survival percentage, and proportion of brachypterous females have a significant linear relationship to damage score and rice resistance to BPH. Nymphal survival is the most direct way of host plant resistance and its effect on pest population build-up.

\section{Conclusion}

We found that $D B 1$ transgene improved resistance by one level against BPH biotype 2 from susceptible to moderately resistant. There was a difference between the feeding behavior of BPH and its preference for laying eggs. $D B 1$ transgene is less effective against both biotypes (2 and 3). Two genotypes, i.e., PTB-33 and Rathu Heenati were highly resistant to these two colonies and may be a promising source of BPH resistant genes against some ever-growing biotypes of $\mathrm{BPH}$. Although DB1 gene improve one resistant level, DB1 
transgenic rice line offers environmentally friendly approach for protecting rice from BPH attack. Pyramiding this gene with other genes would be beneficial for developing BPH resistant rice.

\section{Acknowledgements}

The authors wish to thank Ms. Nuri K. Willis, Ms. Ristiani Amalia and Ms. Junengsih for helping in collecting data and to Universitas Padjadjaran for partly funding the research.

\section{Author Contributions}

NC, GIP and DD planned the experiments, GIP, SS, DD and NC interpreted the results, GIP, KT and NC made the write up, DD and SS statistically analyzed the data and made illustrations, KT provided genetic materials.

\section{Conflicts of Interest}

All authors declare no conflicts of interest.

\section{Data Availability}

Data presented in this paper will be available on a fair request to the corresponding author.

\section{Ethics Approval}

Not applicable in this paper.

\section{References}

Cheng X, L Zhu, G He (2013). Towards understanding of molecular interactions between rice and the brown planthopper. Mol Plant 8:621-634

Gaidamashvili M, Y Ohizumi, S Iijima, T Takayama, T Ogawa, K Muramoto (2004). Characterization of yam tuber storage proteins from Dioscorea batatas exhibiting unique lectin activities. J Biol Chem 279:26028-26035

Horgan FG, AP Cruz, CC Bernal, AF Ramal, MLP Almazan, A Wilby (2018). Resistance and tolerance to the brown planthopper, Nilaparvata lugens (Stål), in rice infested at different growth stages across a gradient of nitrogen applications. Field Crops Res 217:53-65

IRRI (2013). Standard Evaluation System for Rice (SES), $5^{\text {th }}$ edn, p:65. International Rice Research Institute (IRRI), Philippines

Jairin J, K Phengrat, S Teangdeerith, A Vanavichit, T Toojinda (2007a). Mapping of a broad-spectrum brown planthopper resistance gene, Bph3, on rice chromosome 6. Mol Breed 19:35-44

Jairin J, S Teangdeerith, P Leelagud, K Phengrat, A Vanavhicit, T Toojinda (2007b). Detection of brown planthopper resistance genes from different rice mapping populations in the same genomic location. Sci Asia 33:347-352
Jena KK, SM Kim (2010). Current status of brown plant hopper (BPH) resistance and genetics. Rice 3:161-171

Kato T, M Hori, T Ogawa, K Muramoto, K Toriyama (2010). Expression of gene for Dioscorea batatas tuber lectin 1 in transgenic tobacco confers resistance to green-peach aphid. Plant Biotechnol 27:141-145

Kumari A, N Kaushik (2016). Oviposition deterrents in herbivorous insects and their potential use in integrated pest management. Ind J Exp Biol 54:163-174

Ling Y, Z Weilin (2016). Genetic and biochemical mechanisms of rice resistance to planthopper. Plant Cell Rep 35:1559-1572

Manuwoto S, H Adijuwana (1991). Mechanisms and chemicals factors that underlying resistance of some rice varieties to the brown planthopper stem Nilaparvata lugens Stal (Homoptera: Delphacidae) (in Bahasa Indonesia). J Pertan Indones 1:5-13

Maqbool SB, S Riazuddin, NT Loc, AMR Gatehouse, JA Gatehouse, P Christou (2001). Expression of multiple insecticidal genes confers broad resistance against a range of different rice pests. Mol Breed 7:85-93

Matsumura M, S Sanada-Morimura, T Fujii (2017). Manual for Testing Insecticide Susceptibility in Rice Plant Hoppers, p:27. Kyushu Okinawa Agricultural Research Center, National Agriculture and Food Research Organization (KARC/NARO), Japan

Nagadhara D, S Rameshi, IC Pasalu, YK Rao, NP Sarma, VD Reddy, KV Rao (2004). Transgenic rice plants expressing snowdrop lectin genes (GNA) exhibit high-level resistance to the white backed plant hopper (Sogatella furcifera). Theor Appl Genet 109:1399-1405

Nanda S, PJ Wan, SY Yuan, FX Lai, WX Wang, Q Fu (2018). Differential responses of $O S M P K s$ in IR56 rice to two BPH populations of different virulence levels. Intl J Mol Sci 19; Article 4030

Nugaliyadde L, DS Des-Abeysiriwarden, LGA Samanmalee, R Pathirana, RMI Wilkins (2007). Inheritance of resistance in rice to brown planthopper: Its implications on rice varietal improvement in Sri Lanka. http://www.goviya.lk/agri_learning/ Paddy/Paddy_Research/ Paddy_pdf/P3.pdf.

Ohizumi Y, M Gaidamashvili, S Ohwada, K Matsuda, J Kominami, S Nakamura-Tsuruta, J Hirabayashi, T Naganuma, T Ogawa, K Muramoto (2009). Mannose-binding lectin from yam (Discorea batatas) tubers with insecticidal properties against Helicoverpa armigera (Lepidoptera: Noctuidae). $J$ Agric Food Chem 57:2896-2902

Pathak MD, ZR Khan (1994). Insect Pests of Rice. International Rice Research Institute. Manila, Philippines

Rashid MM, M Jahan, KS Islam (2016). Impact of nitrogen, phosphorus and potassium on brown planthopper and tolerance of its host rice plants. Rice Sci 23:119-131

Santhanalakshmi S, S Saikumar, S Rao (2010). Mapping genetic locus linked to brown planthopper linked to rice Oryza sativa L. Intl $J$ Plant Breed Genet 4:13-22

Sarao PS, JS Bentur (2018). Quantification of antibiosis levels in nine different rice genotypes against Nilaparvata lugens (Homoptera: Delphacidae). Intl J Trop Ins Sci 38:330-339

Toriyama K (2010). Production of transgenic plants expressing Dioscorea batatas tuber lectin $1(D B 1)$ to confer resistance against sup-sucking pests. In: Proceedings of International Seminar on Biotechnology for Enhancement the Tropical Biodiversity, October 19-20, 2020. Universitas Padjadjaran, Bandung, Indonesia

Wang J, L Song, X Gong, J Xu, M Li (2020). Functions of jasmonic acid in plant regulation and response to abiotic stress. Intl J Mol Sci 21; Article 1446 